\title{
Evaluation of Some Root-knot Nematode Management Strategies in Sugarbeet Fields at West Nubaryia District
}

Rady, G. H. H.; Abdelnabby, H. M.; Gohar, I. M. A.; Mohamed, Gh. R. Y.; and Sabra, T. F. Y.

Plant Protection Dept., Fac., Agric., Benha Univ., Egypt.

Corresponding author: gad.hamada@ @agr.bu.edu.eg

\begin{abstract}
Two field trials were carried out in west Nubaria district, throughout two successive seasons of 2016/2017 - 2017/2018 to evaluate multiple strategies based on reducing the interval between seeding and seedling emergence, by increasing the speed of germination and seedling emergence to offer the most important escape strategy from soil-borne pathogens, the acceleration of germination and plant emergence and sometimes the improvement of seed viability and the acceleration of seedling growth was done by means of what so called EPD (Early Plant Development or fast initial growth) under protection using certain nematicides. Along with those field trials, pot experiment was done at outdoor for 60 days to assess host suitability (resistance) designations of studied varieties i.e. Beta vulgaris subsp. Vulgaris, Sahar var. and Helsinki to root-knot nematode, Meloidogyne incognita. Experimental design was a factorial arranged split-split plot with variety as main plot, plowing depth as split plot in the form of strip-plot arrangement of six treatments and treatment as split-split with four replicates was used. Quantitative scheme for assignment of Canto-Saenz's host suitability for root-knot nematode showed that sugarbeet variety, Helsinki is tolerant and Sahar variety is susceptible. Evaluated treatments i.e. strategies were varied combinations their components consisted from EPD, Abamectin, Oxamyl 10\% G and Nemastop and were compared with control treatment. Analysis of variance for the combined data of the studied two seasons significantly at $\mathrm{P} \leq 0.05$ marked out the effect of various treatments. Studied Treatments impact individually or in combinations on root-knot nematode parameters, as nematodes number/g soil, knot disease severity \% and drop rate $\%$ results indicated that sugarbeet variety Helsinki overcame Sahar variety positively for the abovementioned parameters; also, $30 \mathrm{~cm}$-plowing depth outperformed the other two depths in the same issues. Managements treatments distinctly revealed that (EPD + Nemastop), (Nemastop) and (EPD) achieved the best results to reduce all studied root-knot nematode parameters Most likely with a plowing depth of $30 \mathrm{~cm}$. Individual treatments showed that at the level of variety, monogerm Helsinki outperformed polygerm variety, Sahar in all abovementioned parameters. At plowing depth level, $30 \mathrm{~cm}$-plowing depth was mostly had superior positive effect on all recorders. At the level of treatments, (EPD + Nemastop) had a distinguish effect on root and sugar yield per fed., sugarbeet variety, Helsinki overcome Sahar variety. Also, $30 \mathrm{~cm}$-plowing depth had the lead in achieving preferred results, as well treatments (EPD + Nemastop), (Nemastop) and (EPD). Interactions of combined treatment as well showed distinguished results for those parameters mentioned above as combined treatments implied one of those distinguish individuals. Interaction effect of combined treatments got promising results as they implied any of individual treatment that previously showed positive results concerning the same nematode parameters.
\end{abstract}

Keywords: sugarbeet -root-knot nematodes - seed treatment - plowing depth - EPD - nematicides.

\section{Introduction}

Sugarbeet, Beta vulgaris var. Saccharifera L. was the second major sugar crop grown in newly reclaimed soil. Sugarbeet, which contributed. Currently, in Egypt sugarbeet is deliberated as the first sugar crop in Egypt cultivated in 492.708 feddans contributing $57.7 \%$ of sugar production with an average production of 21.06 tons per feddan (Annual Report of Sugar Crops Council, December 2018). Increase in production is attributed to higher procurement prices especially for sugarbeets (GAIN Report, 2019).

As sugarbeet production growing, challenges augmenting, among these challenges in newly reclaimed soils the root knot nematodes are included within the genus Meloidogyne Goldi, and belong to a comparatively small but important polyphagous assemblage of extremely adapted obligate plant pathogens (Abad et al., 2003). Due to their endoparasitic mode of living and feeding, root knot nematodes interrupt the physiology of the plant and able to cause great losses in production and quality of sugarbeet crop (Gohar and Maareg, 2005) and, therefore, are of great economic importance and compile control strategies is required. Chemical nematicides, due to their high availability and easy applicability, are usually preferred for their effective control; though, their excessive and continues use caused direct toxicity to predators, pollinators, fish and man, had adverse effects on soil health and environment and cause poor soil fertility, productivity and pesticides residues in products. The problems associated with nematicides application turned the workers vision to focus on new strategies and new alternative agents for nematode management programs in sugarbeet production. Historically, growers have utilized whole field nematode control strategies because of their incapability to position and recognize areas of differing nematode densities to allocate application of nematicides in a site-specific approach inside fields (Evans et al., 2002). Sitespecific application of nematicides offers a chance to 
get better nematode control efficiency. Use of treated seed can reduce chemical use by $99.4 \%$ compared to aerial applications and $88 \%$ compared to a banded infurrow treatment (Frye, 2009). The use of seed treatment, however, is an attractive alternative for nematode control since it requires less chemical input than large scale field nematicide applications, thereby reducing environmental impact and lowering investment costs. Chemical seed treatment is only active in the rhizosphere of soil surrounding the root system of young plants and therefore reduces the risk of undesired accumulation. Treating seeds directly reduces the high cost associated with all other application forms and reducing effects on beneficial and compatible with other IPM strategies (Gohar et. al. 2014).

The more advanced for seed treatment is the main objective for this study through experiencing new strategy depend on reducing the interval between seeding and seedling emergence, by accelerating the speed of germination and seedling emergence to offer the most important escape strategy from soil-borne pathogens.

To achieve these goal new technological solutions were employed in this investigation known EPD (Early Plant Development or fast initial growth). They are characterized by the application of special technologies of seed (Kolarić et. al, 2015). These procedures seeds are practically "be activated", has a faster initial growth, balanced germination, faster assembly lines under protection by proper nematicide which expectantly may result reduction in root-knot disease severity and superior productivity.

\section{Materials and Methods}

2.1. Plant Materials. Seeds of the tested sugarbeet varieties Helsinki as monogerm variety and Sahar as polygerm (Germany and Netherlands, respectively), (CECD 2019).Varieties were commercial and obtained from the certified sugarbeet varieties pool of Alexandria Sugar Company.

2.2. Nematicides and substances used:

2.2.1 Abamectin $^{\circledR}$ as liquid formulation is a macrocyclic lactone derived from the soil bacterium Streptomyces avermitilis that has been shown to have nematicidal properties (Putter et al. 1981) and a different mode of action than the other currently available nematicides (Tuner and Schaeffer, 1989). The rate of application $40 \mathrm{ml}$ feddan-1

2.2.2. Oxamyl (Vydate ${ }^{\circledR}$ ) a granule containing $10 \%$ $\mathrm{w} / \mathrm{w}$ for the suppression of nematodes in potatoes, beet, carrots and parsnips. Active ingredient Oxamyl (carbamate).... Apply the granules at $0.03 \mathrm{~kg} / 100 \mathrm{~m}$ in the seed furrow at drilling to a minimum depth of $2.5 \mathrm{~cm}$, Apply Vydate ${ }^{\circledR} 100$ GR into planting furrow before irrigation.

2.2.3. Nemastop ${ }^{\circledR}$ as suspension formulation is a natural product consist of herb Allium sativum (garlic) extracts (thio- compounds - Allyl Disulfide + Allyl cysteine) 8\% (Harris et.al. 2001) and natural organic matter effective in fighting nematodes. The rate of application $10 \mathrm{~L} \mathrm{feddan}^{-1}$

2.3. Preservative substances for accelerating germination and growth used (Early Plant Development- EPD): A combination of Biplantol ${ }^{\circledR}$, humic acids and Stockosorb ${ }^{\circledR}$ have been employed in coating seeds:

2.3.1. Biplantol ${ }^{\circledR}$, an organic, homeopathic product supposed to promote root development (Bioplant Naturverfahren GmbH, Konstanz, Germany).

2.3.2. Humic acid, known to improve water penetration into seeds, promote germination, and stimulate root growth (Mackowiak et al. 2001; Atiyeh et al. 2002).

2.3.3. Stockosorb ${ }^{\circledR}$ : It is a cross-linked potassium based polyacrylate/ polyacrylamide hydrophilic polymer which is nutrient free (Ghebru et al. 2007; Gorim et al. 2009).

The combination of above agents represented the coating of the sugarbeet seeds, coat share $\%$ as the mass of the coated seeds; the optimum coat share used was coat share $50-75 \%$ and calculated as follows:

Coat.share. $\%=\frac{\text { Mass.of .individual.coated } . \text { seed }- \text { Mass.of.individual.uncoated.seed }}{\text { Mass of coated seed }} \times 100$ (Gorim, 2014)

2.4. Experimental Fields and Sugarbeet Growing Conditions. The experimental site located at Adam Village, Tiba Supervision, West Nubaria Sector $\left(30^{\circ} 37^{\prime} 31.40^{\prime \prime} \mathrm{N}, 29^{\circ} 58^{\prime} 9.26^{\prime \prime} \mathrm{E}\right)$, which was naturally infested with Meloidogyne incognita in. The soil type was sandy soil containing distinctly low percentage of organic matter $(0.39 \%)$, with a $\mathrm{pH}$ of 8.01 . The average particle size distribution was $87.2 \%$ sand, 6.5 $\%$ fine sand, $2.0 \%$ silt and $4.3 \%$ clay. The field had been planted for sugarbeet for numerous years before launching this study. Sowing dates for the two field experiments were at 18th of October 2017 and 2018. Three levels of plowing depth were conducted ( $\mathrm{P} 1=30$ $\mathrm{cm}, \mathrm{P} 2=40 \mathrm{~cm}$ and $\mathrm{P} 3=50 \mathrm{~cm}$ ). The used plow was chisel plow with Standards number of 7 blades arranged on two rows, the first one with 3 blades and the second with 4 blades, spacing between blades 45 $\mathrm{cm}$, the plow gullet measured $75 \mathrm{~cm}$, plowing depth is changeable controlled by the two wheels of depth adjusting (Gauge wheels), maximum depth reaches 55 $\mathrm{cm}$, the used tractor was Fiat ${ }^{\circledR} 4 \times 4$ wheel drive with capacity of $130 \mathrm{hp}$. Conventional crop management was followed as recommended for sugarbeet production in the region. All crop production practices were performed by the grower, and fertilization was based on soil nutrient analysis. Irrigation was drip irrigation system $50 \times 20 \mathrm{~cm}$. In the drip irrigation system, polyethylene drip lines of $16 \mathrm{~mm}$ in diameter had in-line type emitters. The distance between 
emitters along the drip line was $0.33 \mathrm{~m}$ and the discharge of one emitter was $4 \mathrm{~L} /$ fed. under the running pressure of $1.5 \mathrm{~atm}$.

2.5. Experimental design was a factorial arranged split-split plot with plowing depth as main plot, variety as split plot in the form of strip-plot arrangement of treatments and treatment as split-split with four replicates was used. Sub-subplots consisted of six rows $(50 \mathrm{~cm}$ spacing) by $7.0 \mathrm{~m}$ in length $(3 \mathrm{~m} \times 7.0 \mathrm{~m}$
$=21.0 \mathrm{~m} 2$ ) i.e. $1 / 200$ Fed. with four replicates. The experimental setup was repeated for the succeeding trial in 2018.

2.6. Soil Disinfestations Treatments were applied to individual plots. Five treatments plus an untreated control were established in a randomized complete plot design with four replicates per treatment at each location every season.

\begin{tabular}{ccc}
\hline Treatment symbols & Soil Treatment & Application \\
\hline $\mathrm{T}_{1}$ & EPD & Seed treatment (coating) \\
$\mathrm{T}_{2}$ & Nemastop $^{\circledR}$ & Seed treatment (soaking) \\
$\mathrm{T}_{3}$ & Vaydet $^{\circledR}$ & In the seed furrow at drilling \\
$\mathrm{T}_{4}$ & ${\text { EPD }+ \text { Abamectin }^{\circledR}}^{\circledR}$ & Seed treatment (coating + soaking) \\
$\mathrm{T}_{5}$ & $\mathrm{EPD}+$ Nemastop & Seed treatment (coating + soaking ) \\
$\mathrm{T}_{6}$ & Control & Standard seed \& free furrow of chemicals \\
\hline
\end{tabular}

2.7. Nematode soil population densities were estimated from composite soil samples were taken from each plot just before applying the soil disinfestations treatments $(\mathrm{P} 0)$ and after the treatments at planting $(\mathrm{Pi})$ to determine soil nematode densities. On each sampling time, twelve soil cores were taken per plot using a vertical soil core sampler and cores were mixed in a composite soil sample. Nematodes were extracted from sub-samples using a modified Bearman's tray method as described by Barker (1985), where at harvest, $P_{f}$ was determined by taking composite soil samples dug with a spade around the roots of 10 to 12 plants distributed randomly at each site. Nematodes were extracted using a modified Bearman's tray method as described by Barker (1985), and identified and counted under a compound microscope. To identify the Meloidogyne species, ten females were collected from infected roots under a stereo microscope. to identify the RKN species in accordance with their perineal pattern.

2.8. Host suitability resistance designations of studied varieties i.e. Beta vulgaris subsp. Vulgaris, Sahar var. and Helsinki: The host efficiency (reproduction factor 'RF') was calculated, where ' $R F$ ' $=\mathrm{Pf} / \mathrm{Pi}$, with $\mathrm{Pf}$ being final population in $250 \mathrm{~cm} 3$ of soil and $\mathrm{Pi}$ being the initial inoculums. Final assessment of the various genotypes was based on modified Canto-Saenz's host resistance designations scheme (Gohar et al., 2013) as given in (Table, $\mathrm{A}$ ).

Table (A):-Adapted Quantitative scheme for assignment of Canto - Saenz's host suitability (resistance) designations modified for sugarbeet by (Gohar et. al. 2013).

\begin{tabular}{|c|c|c|}
\hline Degree of resistance (DR) & Host efficiency ${ }^{\mathrm{z}}$ (R-factor) & Plant Damage $(\text { Gall index })^{\mathrm{y}}$ \\
\hline Resistant (R) & $\leq 1$ & $\leq 2$ \\
\hline Moderately Resistant (MR) & $\leq 1$ & $\approx 2$ \\
\hline Tolerant $(\mathbf{T})$ & $>1$ & $\leq 2$ \\
\hline Susceptible (S) & $>1$ & $>2$ \\
\hline Hyper susceptible (HYS) & $\leq 1$ & $>2$ \\
\hline
\end{tabular}

2.9. Assessment of tested nematodes management strategies efficacy \% against the root-knot nematode on sugarbeet. To evaluate the experimented efficacy $\%$ of management strategies against root-knot nematode, the numbers of nematodes in the soil and disease severity were determined. The nematode numbers in the soil were detected by Baermann funnel apparatus. Finally, the first couple of drops of water from the bottom of the tube were gathered by slowly releasing the clamp on the tubing, and then the density of larvae was examined under the microscope. For the disease severity detection, the gall indices we rerecorded at the termination of experiments on the scale rating chart as described above. The six-control strategies efficacy was calculated as described by (Xue et al. 2009).

Disease severity, drop rate $\%$ and control strategies efficacy were calculated as following:

\section{Disease severity $\%=$}

$\left[\sum \frac{\text { the.number.of.root }- \text { knot.disease.plants.in.this.index } \times \text { disease.index }}{\text { total.plants.investigated } \times \text { highest.root.index }- \text { knot.disease.index }} \times 100 \%\right]$ 
Drop rate $\%=$

the.number.of.J2.in.control.treatment - the.number.of.J2.in.strategy.management.treatment $\times 100 \%$ the..number.of.J2.in.control.treatment

\section{Management strategy efficacy $\%=$}

disease..severity.in.control.treatment - disease..severity.in.strategy.treatment $\times 100 \%$ disease severity.in.control treatment

\subsection{The impact of strategy treatments on the yield} of sugarbeet as roots and sugar ton/fed.

\section{Data Recorded:}

In each plot (sub- plot), the outer two ridges $\left(1^{\text {st }}\right.$ and $6^{\text {th }}$ ) were considered as a belt, while, the $2^{\text {nd }}$ and $5^{\text {th }}$ ridges were devoted for plant growth sampling, the two central ridges to determine roots and top yields at harvest. The collected data in the two experiments involved the following traits:

\section{Yield characters:}

1- Root yield (tons/ fed).

2- Sugar yield (tons/ fed) $=$ Roots yield $/$ fed $\times$ Sucrose \% according to the equation given by (Suheri, 2007).

\section{Statistical analysis:}

Bartlett's test (Snedecor and Cochran, 1989)

is used to examine the null hypothesis, homogeneity of variances for the two season's records, thus, data of the two seasons were combined for analysis of variance (ANOVA) according to Steel and Torrie (1981). using MSTAT version 4 (1987), followed by testing significant differences among the means of different treatments were separated by Duncan's Multiple Range Test at 0.05 probability according to Duncan (1955).

\section{Results and discussion}

\section{Host suitability resistance/ susceptibility designations of studied varieties for root-knot nematode, $M$. incognita:}

The resistance/susceptibility of two sugarbeet varieties was measured by gall index (GI) as an indicator for plant damage, and host efficiency ( $R$ factor) as an indicator for nematode reproduction according to Quantitative scheme for assignment of Canto-Saenz's host suitability (resistance) - (CantoSaenz host suitability designations modifications by Gohar et. al., 2013).

The result of the varietal assessment is illustrated on Table (A), revealed that Helsinki variety supported relatively high nematode reproduction $(\mathrm{R}>1)$ with fairly plant damage $(\mathrm{GI} \leq 2)$ and was therefore rated as tolerant. The subsequent category implied sugarbeet variety Sahar which supported nematode reproduction $(\mathrm{R}>1)$ with high plant damage $(\mathrm{GI}>2)$ and was therefore rated as susceptible (Table, 1 ).

Table 1. Host suitability (resistance) Designations of studied varieties i.e. Beta vulgaris subsp. Vulgaris, Sahar var. and Helsinki tested for root-knot nematode, $M$. incognita

\begin{tabular}{lcccl}
\hline Sugarbeet varieties & $\begin{array}{c}\text { Root gall } \\
\text { index }\end{array}$ & $\begin{array}{c}\mathbf{J 2 / 2 5 0} \mathbf{~ c m}^{\mathbf{3}} \text { of } \\
\text { Soil }(\mathbf{P i})\end{array}$ & $\begin{array}{c}\text { R-factor host } \\
\text { efficiency** }\end{array}$ & Host status*** \\
\hline Polygerm Sahar & 3.4 & 921 & 2.3 & Susceptible \\
Monogerm Helsinki & 1.7 & 959 & 2.4 & Tolerant \\
Mean & 2.6 & 940 & 2.4 & \\
LSD 0.05 & 1.1 & 386 & & \\
\hline
\end{tabular}

*Gall index: $0=$ no gall formation; $5=$ heavy gall formation.

***eproduction factor: $\mathrm{R}=\mathrm{Pf} / \mathrm{Pi}$, where $\mathrm{Pi}$ =initial population $\left(400 \mathrm{~J} 2 / 250 \mathrm{~cm}^{3}\right.$ soil $)$ density and $\mathrm{Pf}=$ final population density

*** Host status based on Canto-Saenz host suitability designations modified for sugarbeet by Gohar et. al., 2013)

Gohar et. al. (2013) concluded there are three categories for sugarbeet varieties as response to $M$. incognita, the first seriously affected the second included reasonably affected varieties as Tolerant ones and the third as severely affected with nematode represented variety as Hyper susceptible one.

\section{Effect of multiple Management approaches on root- knot nematodes number/g soil:}

Denoting to results in Table (2), the monogerm sugarbeet variety, Helsinki harbored an average of number of 2.7 larvae/ g soil significantly less than those harbored by polygerm variety Sahar (2.8 larvae/g soil). Also, plowing depth had some effect on the number of larvae / $\mathrm{g}$ soil, whereas $30 \mathrm{~cm}$-plowing depth scored the lower number (2.3 larvae/g soil). All studied plowing depths varied significantly at $\mathrm{P} \leq 0.05$ than each others.

From Table (2), evaluation the effect of management treatments on root-knot nematode number as larvae /g soil compared with the control treatment, showed that all tested treatments significantly reduced the population of root-knot nematode in the soil, also it could be noticed that there were significant differences among all tested managements at $\mathrm{P} \leq 0.05$. The best record was for treatment $\mathrm{T}_{2}$ (Nemastop) - 2.4 larvae / g soil, followed by $\mathrm{T}_{5}$ (EPD + Nemastop) -2.8 larvae / g soil. 
Table 2. Effect of multiple Management approaches on root- knot nematodes number/g soil, in sugarbeet field by combine analysis of 2016/17 and 2017/ 18 growing seasons.

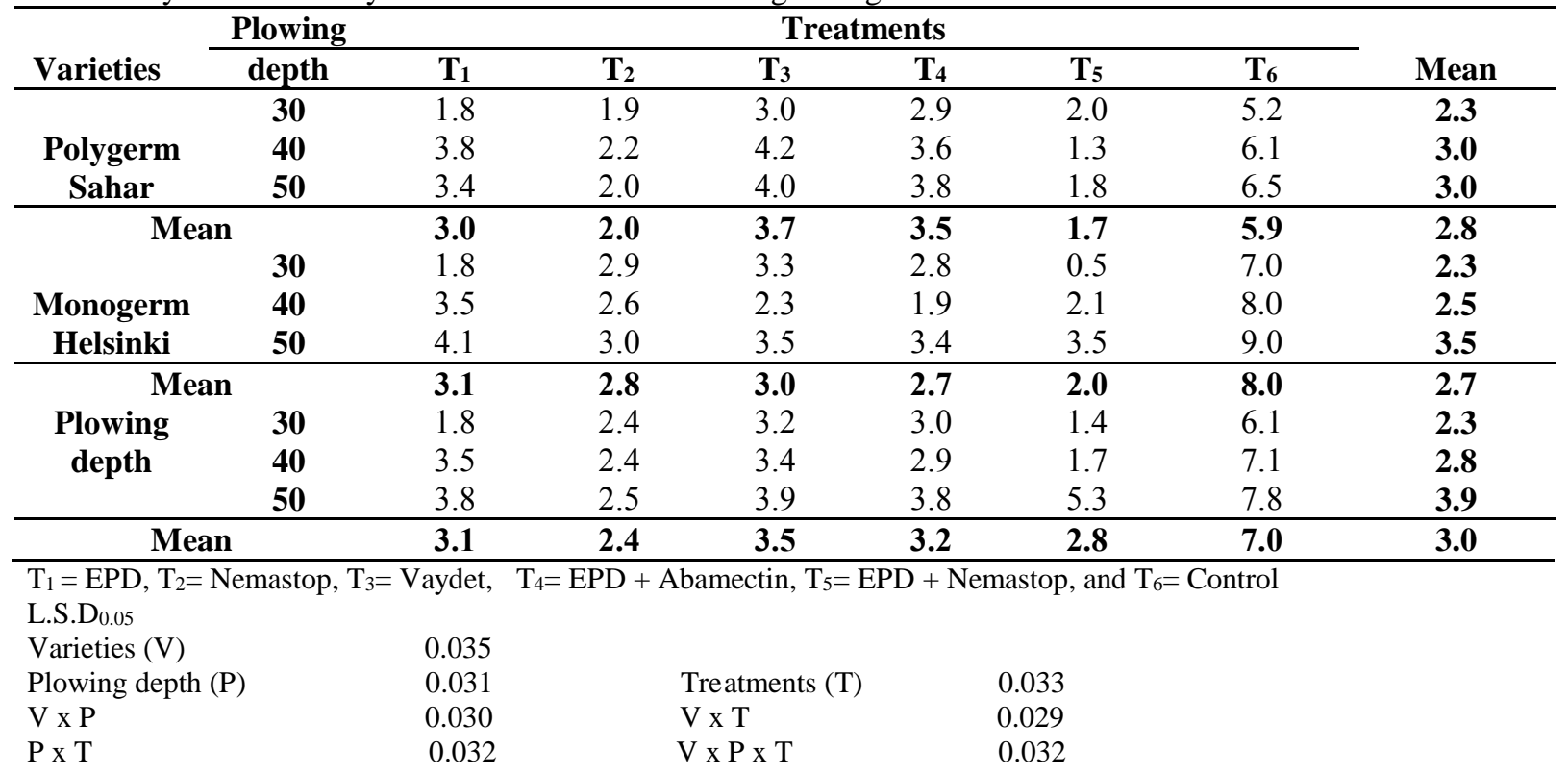

The interaction effect of combined treatments for variety $\times$ plowing depth on number of root-knot nematode larvae / g soil had significant differences among them at $\mathrm{P} \leq 0.05$. Sugarbeet varieties, Helsinki and Sahar recorded the same value of lowering population $\mathrm{f}$ root-knot nematode larvae at $30 \mathrm{~cm}-$ plowing depth (2.3 larvae /g soil), the least effect was with Helsinki variety at $50 \mathrm{~cm}$-plowing depth $(3.5$ larvae /g soil). Interaction effect of combined treatments for variety $\times$ Management treatments on population of root-knot nematode / $\mathrm{g}$ soil showed that there were significant differences among those combinations at $\mathrm{P} \leq 0.05$. Sugarbeet variety, Sahar had the lead to reduce root-knot nematode larvae with treatment $\mathrm{T}_{5}$ (EPD + Nemastop) - 1.7 larvae / g soil followed by Helsinki variety with the same treatment (2.0 larvae / $\mathrm{g}$ soil), followed by Sahar variety with $\mathrm{T}_{2}$ (Nemastop) - 2.0 larvae /g soil. All interaction effect for variety $\times$ plowing depth had significant differences among them at $\mathrm{P} \leq 0.05$ never the less the all had satisfactory effect to reduce population of root-knot nematode compared with control treatment (Table, 2).

From same Table (2), results confirmed that interaction effect of plowing depth $\times$ management treatments on larvae numbers / $\mathrm{g}$ soil achieved significant differences among them at $\mathrm{P} \leq 0.05$. The most influence combination was $30 \mathrm{~cm}$-plowing depth with $\mathrm{T}_{5}$ (EPD + Nemastop) - 1.4 larvae / $\mathrm{g}$ soil followed by $40 \mathrm{~cm}$-plowing depth with the same treatment (1.7 larvae / g soil), followed by $30 \mathrm{~cm}$ plowing depth with $\mathrm{T}_{1}$ (EPD) -1.8 larvae / g soil.

The combined treatments of variety $\times$ plowing depth $\times$ management treatment $(\mathrm{V} \times \mathrm{P} \times \mathrm{T})$ had significant interaction effect mostly at $\mathrm{P} \leq 0.05$ on larvae numbers / $g$ soil. Among all combinations there were significant differences, in the front, sugarbeet variety, Sahar at $40 \mathrm{~cm}$-plowing depth with treatment $\mathrm{T}_{5}$ (EPD + Nemastop) had the lowest larvae number /g soil (1.3), followed by the same variety at $30 \mathrm{~cm}$ depth with treatment $\mathrm{T}_{1}=\mathrm{EPD}$ (1.8 larvae/ $\mathrm{g}$ soil), followed by variety Helsinki at $30 \mathrm{~cm}$-plowing depth with treatment $\mathrm{T}_{1}=\mathrm{EPD}$ by the same value (1.8).

\section{Effect of multiple approaches for controlling root- knot nematodes on disease severity $\%$ in sugarbeet:}

Results in Table (3) revealed that calculated disease severity $\%$ for the two tested sugarbeet varieties, differed significantly at $\mathrm{P} \leq 0.05$, whereas, the monogerm variety, Helsinki got an average of rootknot disease severity $17 \%$, while, the polygerm variety, Sahar got disease severity \% greater than Helsinki (26.5\%). Plowing depth recorded significant difference among the at $\mathrm{P} \leq 0.05$, the highest disease severity \% recorded for $40 \mathrm{~cm}$-plowing depth. Management treatments had occasionally significant difference among them at $\mathrm{P} \leq 0.05$, treatment of $\mathrm{T}_{5}$ (EPD + Nemastop) achieved the best result whereas it had the lowest disease severity (13.1\%), followed by treatment $\mathrm{T}_{2}$ (Nemastop) - (14.9\%). All management treatments reduced root-knot severity $\%$ significantly compared with control treatment $(35.1 \%)$.

Interaction effect of combined treatments on rootknot disease severity \% showed in Table (3) confirmed that variety $\times$ plowing depth had significant differences among them at $\mathrm{P} \leq 0.05$, sugarbeet variety, Helsinki at $40 \mathrm{~cm}$-plowing depth and at $30 \mathrm{~cm}$ followed by the same variety with $50 \mathrm{~cm}$-plowing depth reduced root-knot disease severity to $16.4 \%$, $16.6 \%$ and $17.9 \%$, respectively. The best reduction of disease severity \% to Sahar variety was with $50 \mathrm{~cm}$ plowing depth $(21.4 \%)$. Interaction variety $\times$ Management treatments reduced root-knot disease severity \% compared with control, the best reduction was obtained by sugarbeet variety, Helsinki with treatment $\mathrm{T}_{5}(\mathrm{EPD}+\mathrm{Nemastop})-13.1 \%$, followed 
by sugarbeet variety, Sahar with the same treatment $\left(\mathrm{T}_{5}\right)-14.3 \%$, followed by Sahar variety with $\mathrm{T}_{2}$ (Nemastop) $-14.7 \%$, followed by Helsinki variety with treatment $\mathrm{T}_{4}(\mathrm{EPD}+$ Abamectin $)-14.8 \%$. All combined treatments of variety and management treatments reduced root-knot severity $\%$ significantly compared with control treatment at $\mathrm{P} \leq 0.05$.

Table 3. Effect of multiple approaches for controlling root- knot nematodes on disease severity $\%$ in sugarbeet field by combine analysis of 2016/ 17 and 2017/ 18 growing seasons.

\begin{tabular}{|c|c|c|c|c|c|c|c|c|}
\hline \multirow{2}{*}{ Varieties } & \multirow{2}{*}{$\begin{array}{l}\text { Plowing } \\
\text { depth }\end{array}$} & \multicolumn{6}{|c|}{ Treatments } & \multirow{2}{*}{ Mean } \\
\hline & & $\overline{T_{1}}$ & $\overline{T_{2}}$ & $\mathbf{T}_{3}$ & $\mathbf{T}_{4}$ & $\mathbf{T}_{5}$ & $\mathbf{T}_{6}$ & \\
\hline \multirow{3}{*}{$\begin{array}{l}\text { Polygerm } \\
\text { Sahar }\end{array}$} & 30 & 14.8 & 15.2 & 22.8 & 22.2 & 17.2 & 90.3 & 30.4 \\
\hline & 40 & 26.0 & 15.1 & 31.0 & 23.3 & 12.3 & 58.6 & 27.7 \\
\hline & 50 & 20.3 & 13.8 & 25.0 & 23.2 & 13.5 & 32.5 & 21.4 \\
\hline \multicolumn{2}{|c|}{ Mean } & 20.4 & 14.7 & 26.3 & 22.9 & 14.3 & 60.5 & 26.5 \\
\hline \multirow{3}{*}{$\begin{array}{c}\text { Monogerm } \\
\text { Helsinki }\end{array}$} & 30 & 13.0 & 16.7 & 18.1 & 16.3 & 10.3 & 25.0 & 16.6 \\
\hline & 40 & 17.1 & 14.1 & 13.5 & 12.7 & 13.0 & 28.2 & 16.4 \\
\hline & 50 & 17.6 & 14.4 & 15.9 & 15.5 & 15.9 & 28.3 & 17.9 \\
\hline \multicolumn{2}{|c|}{ Mean } & 15.9 & 15.1 & 15.8 & 14.8 & 13.1 & 27.2 & 17.0 \\
\hline \multirow{3}{*}{$\begin{array}{l}\text { Plowing } \\
\text { depth }\end{array}$} & 30 & 13.8 & 15.9 & 20.3 & 18.6 & 12.5 & 36.1 & 19.5 \\
\hline & 40 & 20.3 & 14.8 & 18.6 & 16.3 & 12.4 & 38.2 & 20.1 \\
\hline & 50 & 19.1 & 14.1 & 19.1 & 18.6 & 14.4 & 31.0 & 19.4 \\
\hline \multicolumn{2}{|c|}{ Mean } & 17.7 & 14.9 & 19.3 & 17.8 & 13.1 & 35.1 & 19.7 \\
\hline
\end{tabular}

$\mathrm{T}_{1}=\mathrm{EPD}, \mathrm{T}_{2}=$ Nemastop, $\mathrm{T}_{3}=$ Vaydet, $\mathrm{T}_{4}=\mathrm{EPD}+$ Abamectin, $\mathrm{T}_{5}=\mathrm{EPD}+$ Nemastop, and $\mathrm{T}_{6}=$ Control

$\begin{array}{lc}\text { L.S.D } & \\ \text { Varieties }(\mathrm{V}) & 0.119 \\ \text { Plowing depth (P) } & 0.067 \\ \text { Treatments (T) } & 0.139 \\ \text { V x P } & 0.096 \\ \text { V x T } & 0.196 \\ \text { P x T } & 0.240 \\ \text { V x P x T } & 0.339\end{array}$

The most promising results for reducing root-knot severity as interaction effect of plowing depth $\times$ Management treatments, all were with $\mathrm{T}_{5}$ (EPD + Nemastop), at $40 \mathrm{~cm}, 30 \mathrm{~cm}$ and $50 \mathrm{~cm}$-plowing depths $(12.4,12.5$, and $14.4 \%$, respectably). All plowing depths with treatment $\mathrm{T}_{2}=$ Nemastop had the second rank in reduction of root-knot severity \% compared with control treatment (Table, 3 ).

The combined treatments of variety $\times$ plowing depth $\times$ management treatment $(\mathrm{V} \times \mathrm{P} \times \mathrm{T})$ had significant interaction effect on reduction of root-knot disease severity $\%$ at $\mathrm{P} \leq 0.05$. the best reduction was obtained by Helsinki variety at $30 \mathrm{~cm}$-plowing depth with treatment $\mathrm{T}_{5}$ (EPD + Nemastop) $-10.3 \%$, followed by Sahar variety at $40 \mathrm{~cm}$-plowing depth with treatment $\mathrm{T}_{5}$ (EPD + Nemastop) $-12.3 \%$, followed by $13.0 \%$ reduction of disease severity $\%$ obtained by Helsinki variety at $40 \mathrm{~cm}$-plowing depth with treatment $\mathrm{T}_{5}$ (EPD + Nemastop). All combinations had significant differences among them at $\mathrm{P} \leq 0.05$ (Table, 3 ).

\section{Effect of multiple approaches for controlling} root- knot nematodes on drop rate \%:

Results in Table (4) illustrated drop rate $\%$ as an indicator for efficiency for management trails, whereas, it's a calculation depend on the difference between the number of $\mathrm{J} 2$ in control treatment and the number of $\mathrm{J} 2$ in tested treatment divided on the number of $\mathrm{J} 2$ in control treatment multiplied by $100 \%$, thus, as number of $\mathbf{J} 2$ in tested treatment decreases the value of drop rate $\%$ increases signifying the powerful rate $\%$ of tested management method.

Sugarbeet monogerm variety, Helsinki recorded drop rate $66.0 \%$ greater than that recorded by polygerm variety, Sahar (53.1) with highly significance at $\mathrm{P} \leq 0.05$. Concerning plowing depth effect on drop rate $\%$, there were significant difference among three tested plowing depth, in the lead, $30 \mathrm{~cm}$ plowing depth $(61.5 \%)$ followed by $40 \mathrm{~cm}$-plowing depth $(60.6 \%)$ and then $50 \mathrm{~cm}$-plowing depth $(50.5$ $\%)$. All tested management treatments had significant effect on drop rate $\%$, whereas, $\mathrm{T}_{2}$ (Nemastop) got the highest drop rate $\%(64.9 \%)$, followed by $\mathrm{T}_{5}$ (EPD + Nemastop) $-61.8 \%$. The smallest effect on drop rate $\%$ was recorded by T3 (Vaydet) - $49.7 \%$ (Table, 4 ).

Regarding combined treatments interaction effect of variety $\times$ plowing depth on drop rate $\%$ showing in Table (4), confirmed that there were significant differences among combined treatments at $\mathrm{P} \leq 0.05$. The soaring effect was $69.2 \%$ for sugarbeet variety, Helsinki at $40 \mathrm{~cm}$-plowing depth, followed by the same variety at $30 \mathrm{~cm}$-plowing depth $(67.7 \%)$ and at $50 \mathrm{~cm}$-plowing depth (61.2). As well combined treatments interaction effect of variety $\times$ management treatments on drop rate $\%$ presented significant differences among them at $\mathrm{P} \leq 0.05$. The combined Helsinki variety $\times \mathrm{T}_{5}$ (EPD + Nemastop), topped obtained values of drop rate $\%(76.1 \%)$, followed with Sahar variety with the same treatment $(70.5 \%)$, whereas, the smallest value was recorded by combined 
treatments of Sahar variety with treatment $\mathrm{T}_{3}$ (Vaydet)

$-37.7 \%$ drop rate (Table, 4$)$.

Table 4. Effect of multiple approaches for controlling root- knot nematodes on drop rate \% in sugarbeet field by combine analysis of 2016/ 17 and $2017 / 18$ growing seasons.

\begin{tabular}{|c|c|c|c|c|c|c|c|c|}
\hline \multirow{2}{*}{ Varieties } & \multirow{2}{*}{$\begin{array}{l}\text { Plowing } \\
\text { depth }\end{array}$} & \multicolumn{6}{|c|}{ Treatments } & \multirow{2}{*}{ Mean } \\
\hline & & $\mathbf{T}_{1}$ & $\mathbf{T}_{2}$ & $\mathbf{T}_{3}$ & $\mathbf{T}_{4}$ & $\mathbf{T}_{5}$ & $T_{6}$ & \\
\hline \multirow{3}{*}{$\begin{array}{c}\text { Polygerm } \\
\text { Sahar }\end{array}$} & 30 & 65.4 & 63.4 & 42.3 & 43.5 & 61.7 & 0.0 & 55.3 \\
\hline & 40 & 37.7 & 63.3 & 31.4 & 41.0 & 78.3 & 0.0 & 50.3 \\
\hline & 50 & 47.1 & 69.3 & 39.2 & 41.1 & 71.6 & 0.0 & 53.7 \\
\hline \multicolumn{2}{|c|}{ Mean } & 50.1 & 65.4 & 37.7 & 41.9 & 70.5 & & 53.1 \\
\hline \multirow{3}{*}{$\begin{array}{c}\text { Monogerm } \\
\text { Helsinki }\end{array}$} & 30 & 74.2 & 58.1 & 53.4 & 59.7 & 93.1 & 0.0 & 67.7 \\
\hline & 40 & 55.9 & 67.9 & 71.5 & 76.3 & 74.2 & 0.0 & 69.2 \\
\hline & 50 & 54.6 & 67.2 & 60.6 & 62.7 & 61.1 & 0.0 & 61.2 \\
\hline \multicolumn{2}{|c|}{ Mean } & 61.5 & 64.4 & 61.8 & 66.2 & 76.1 & & 66.0 \\
\hline \multirow{3}{*}{$\begin{array}{l}\text { Plowing } \\
\text { depth }\end{array}$} & 30 & 69.8 & 60.8 & 47.9 & 51.6 & 77.4 & 0.0 & 61.5 \\
\hline & 40 & 50.8 & 65.6 & 51.5 & 58.6 & 76.2 & 0.0 & 60.6 \\
\hline & 50 & 50.8 & 68.3 & 49.9 & 51.9 & 31.8 & 0.0 & 50.5 \\
\hline \multicolumn{2}{|c|}{ Mean } & 57.2 & 64.9 & 49.7 & 54.0 & 61.8 & & 57.5 \\
\hline
\end{tabular}

$\mathrm{T}_{1}=\mathrm{EPD}, \mathrm{T}_{2}=$ Nemastop, $\mathrm{T}_{3}=$ Vaydet, $\mathrm{T}_{4}=\mathrm{EPD}+$ Abamectin, $\mathrm{T}_{5}=\mathrm{EPD}+$ Nemastop, and $\mathrm{T}_{6}=$ Control

L.S.D $D_{0.05}$

Varieties (V) 0.119

Plowing depth (P) $\quad 0.067$

Treatments $(\mathrm{T})$

$\mathrm{V} \times \mathrm{P} \quad 0.096$

$\mathrm{V} \times \mathrm{T}$

$\mathrm{P} \times \mathrm{T} \quad 0.240$

$\mathrm{V} \times \mathrm{P} \times \mathrm{T}$

Interaction effect on drop rate $\%$ induced by combined treatments plowing depth $\times$ management treatments presented in table (4) revealed significant differences among them at $\mathrm{P} \leq 0.05$. the highest values for drop rate were obtained by $30 \mathrm{~cm}$ plowing $\times \mathrm{T}_{5}(\mathrm{EPD}+$ Nemastop $)-77.4 \%$, followed $40 \mathrm{~cm}-$ plowing depth with the same treatment (T5 - 76.2\%), followed by $30 \mathrm{~cm}$-plowing depth with $\mathrm{T}_{1}$ (EPD) $69.8 \%$ drop rate. On the other hand, the weakest effect was recorded for $30 \mathrm{~cm}$-plowing depth with $\mathrm{T}_{3}$ (Vaydet) $-47.9 \%$ drop rate.

Also, combined treatments of variety $\times$ plowing depth $\times$ management treatment $(\mathrm{V} \times \mathrm{P} \times \mathrm{T})$ had significant interaction effect mostly at $\mathrm{P} \leq 0.05$ on drop rate $\%$. The superior obtained effect was recorded by Helsinki variety $\times 30 \mathrm{~cm}$-plowing depth $\times \mathrm{T}_{5}(\mathrm{EPD}+$ Nemastop) - $\quad 93.1 \%$, followed by combined treatments Sahar variety $\times 40 \mathrm{~cm}$-plowing depth $\times \mathrm{T}_{5}$ (EPD + Nemastop) $-78.3 \%$ followed by Helsinki variety $\times 40 \mathrm{~cm}$-plowing depth $\times \mathrm{T}_{4}(\mathrm{EPD}+$ Abamectin) $-76.3 \%$ drop rate. The smallest effect recorded by Sahar variety at $40 \mathrm{~cm}$-plowing depth with $\mathrm{T}_{3}$ (Vaydet) $-31.4 \%$ drop rate.

Digesting findings in Tables $2-4$, that illustrating effect of treatment individually or in combinations on root-knot nematode parameters, as nematodes number/g soil, knot disease severity $\%$ and drop rate $\%$. Results indicated that sugarbeet variety Helsinki overcame Sahar variety positively for the abovementioned parameters; also, $30 \mathrm{~cm}$-plowing depth outperformed the other two depths in the same issues. Managements treatments distinctly revealed that $\mathrm{T}_{5}$ (EPD + Nemastop), $\mathrm{T}_{2}$ (Nemastop) and $\mathrm{T}_{1}$ (EPD) achieved the best results to reduce all studied root-knot nematode parameters. Interaction effect of combined treatments got promising results as they implied any of individual treatment that previously showed positive results concerning the same nematode parameters. Considering the tested sugarbeet varieties for susceptibility to $M$. incognita (Table 7) the two cultivars according to Canto-Saenz's host suitability (Sasser et al., 1984) designations modified by (Gohar et. al. 2013)., can be distinguished to two categories, the first involves susceptible variety i.e. Sahar seriously affected by root-knot nematode, $M$. incognita that larger values of nematodes number/g soil, knot disease severity $\%$ and lesser value of drop rate $\%$. The second category in this concern was reasonably affected by root-knot nematode as Tolerant, due to sugarbeet variety, Helsinki which recorded lesser values of nematodes number/g soil, knot disease severity $\%$ and larger value of drop rate $\%$. Results in these Tables (2-4) in full consistency with those in below Tables (6 \& 7). Obviously, Nemastop has reasonable nematicidal effect on rootknot nematodes, Gohar et. al. (2014) revealed that 14 days after planting in plots receiving Nemastop seed treatment showed density of nematode population declined gradually up to the third week (21 DAS) and turn down sharply towards mid-season and considered a promising seed treatment for lowering the population density of root-not nematodes, regarding that Nemastop has nematicidal effect also possess thiocompounds - Allyl Disulfide + Allyl cysteine) $8 \%$ 
which activate as antioxidants (Harris et. al. 2001), that might delay any probable tissue damage in early infestation, these features provide wide spectrum longevity of protection in rhizoplane of the roots . EDP Called EPD (Early Plant Development). They are characterized by the application of particular technologies to seed. These measures applied to seeds are practically "be activated", has a quicker initial growth, balanced germination, closer assembly lines which finally results in superior productivity. Thus, combining EPD with Nemastop would provide faster plant development under protection. The efficiency of seed treatment was more visible under stress germination conditions. In optimum conditions washing and priming speeded up seed germination compared to control seeds. However, under the shortage and excess of water the acceleration of germination of the same seeds took place. Seeds of different sugarbeet varieties differed significantly in their germination rate Orzeszko- Rywka and Podlaski (2003). Since the current study used one sugarbeet seeds varieties (Sahar and Helsinki), hence the variations in germination parameters are due to varying treatments i.e. nematicides and/or EPD as well as varieties. Although, the efficiency of seed treatment depended on initial seed quality, the worse the seed vigor, i.e. the slower the germination, the higher the efficiency of seed treatment (Draycott et al. 2002). But it can be said by other means from the control treatment in this study that seed susceptibility was between susceptible and tolerant for the studied varieties Thus, the promising variation in nematode parameters control is a result mainly for the tested nematicidal seed treatments and EPD technology.

5. Efficacy \% of multiple approaches for controlling root- knot nematodes in sugarbeet fields:

Findings in Table (5) pointed up the calculations of efficacy $\%$ of multiple attempts to control root- knot nematodes in sugarbeet fields by information of disease severity in both control treatment and experienced treatment. There was significant difference between the two tested sugarbeet varieties for their contribution in root-knot nematode control efficacy $\%$, whereas, polygerm sugarbeet variety, and Sahar achieved $61.28 \%$ and monogerm variety, Helsinki achieved $44.83 \%$. At the level of sole treatment of plowing depth, $40 \mathrm{~cm}$-plowing depth scored the highest contribution in root-knot nematode control efficacy $(56.86 \%)$, followed by $30 \mathrm{~cm}-$ plowing depth which contributed in nematode control efficacy by $55.07 \%$ with significant differences along all tested plowing depths at $\mathrm{P} \leq 0.05$. Efficacy \% of root-knot nematode management treatments scored significant variations among them, whereas, treatment $\mathrm{T}_{5}$ (EPD + Nemastop) was at front with control efficacy $62.15 \%$, followed by treatment $\mathrm{T}_{2}$ (Nemastop) which scored control efficacy $57.24 \%$. The smallest control efficacy $\%$ obtained by treatment $\mathrm{T}_{3}$ (Vaydet) - $44.49 \%$.

Table 5. Efficacy \% of multiple approaches for controlling root- knot nematodes in sugarbeet field by combine analysis of 2016/17 and 2017/18 growing seasons

\begin{tabular}{|c|c|c|c|c|c|c|c|c|}
\hline \multirow{2}{*}{ Varieties } & \multirow{2}{*}{$\begin{array}{c}\text { Plowing } \\
\text { depth }\end{array}$} & \multicolumn{6}{|c|}{ Treatments } & \multirow{2}{*}{ Mean } \\
\hline & & $\mathbf{T}_{1}$ & $\mathbf{T}_{2}$ & $\mathbf{T}_{\mathbf{3}}$ & $\mathbf{T}_{4}$ & $\mathbf{T}_{5}$ & $\mathbf{T}_{6}$ & \\
\hline \multirow{3}{*}{$\begin{array}{l}\text { Polygerm } \\
\text { Sahar }\end{array}$} & 30 & 83.61 & 83.17 & 74.75 & 75.42 & 80.95 & 0.00 & 79.58 \\
\hline & 40 & 55.63 & 74.23 & 47.10 & 60.24 & 79.01 & 0.00 & 63.24 \\
\hline & 50 & 37.52 & 57.52 & 23.05 & 28.59 & 58.45 & 0.00 & 41.02 \\
\hline \multicolumn{2}{|c|}{ Mean } & 58.92 & 71.64 & 48.30 & 54.75 & 72.80 & & 61.28 \\
\hline \multirow{3}{*}{$\begin{array}{c}\text { Monogerm } \\
\text { Helsinki }\end{array}$} & 30 & 48.00 & 33.20 & 27.60 & 34.80 & 58.80 & 0.00 & 40.48 \\
\hline & 40 & 39.35 & 49.99 & 52.12 & 54.96 & 53.90 & 0.00 & 50.07 \\
\hline & 50 & 37.81 & 49.12 & 43.82 & 45.23 & 43.82 & 0.00 & 43.96 \\
\hline \multicolumn{2}{|c|}{ Mean } & 41.72 & 44.10 & 41.18 & 45.00 & 52.17 & & 44.83 \\
\hline \multirow{3}{*}{$\begin{array}{l}\text { Plowing } \\
\text { depth }\end{array}$} & 30 & 61.77 & 55.96 & 43.77 & 48.48 & 65.37 & 0.00 & $\mathbf{5 5 . 0 7}$ \\
\hline & 40 & 46.86 & 61.26 & 51.31 & 57.33 & 67.54 & 0.00 & 56.86 \\
\hline & 50 & 38.39 & 54.52 & 38.39 & 40.00 & 53.55 & 0.00 & 44.97 \\
\hline \multicolumn{2}{|c|}{ Mean } & 49.01 & 57.24 & 44.49 & 48.60 & 62.15 & & 52.30 \\
\hline
\end{tabular}

\begin{tabular}{cc}
\hline $\mathrm{T}_{1}=\mathrm{EPD}, \mathrm{T}_{2}=$ Nemastop, $\mathrm{T}_{3}=$ Vaydet, & $\mathrm{T}_{4}=\mathrm{EPD}+\mathrm{A}$ \\
L.S.D 0.05 & 0.119 \\
Varieties (V) & 0.067 \\
Plowing depth (P) & 0.139 \\
Treatments (T) & 0.096 \\
V x P & 0.196 \\
V x T & 0.240 \\
P x T & 0.339 \\
V x P x T &
\end{tabular}


In brief, results in Table (5) pointed out that sugarbeet variety, Sahar contributed in root-knot nematode control efficacy $\%$ by percentage higher that inputted by Helsinki, also, management treatment $\mathrm{T}_{5}$ (EPD + Nemastop) recorded the highest control efficacy $\%$ followed by $\mathrm{T}_{2}$ (Nemastop). $40 \mathrm{~cm}$ and 30 $\mathrm{cm}$-plowing depths scored the higher values of rootknot nematodes control efficacy \%. As regards of interaction effect of combined treatments on control efficacy $\%$, it could be pragmatic that any combined treatment implied any of treatment with richer effect individually resulted in good impact on root-knot nematode control efficacy $\%$.

The computed efficacy $\%$ for management strategy revealed that efficacy depend on the input of every factor involved individually or in combinations, as any of factor performed well realistic return is expected as well as in combination this is in consistency with all above tabulated data. Gohar et. al. (2009) declared that significant performance of the cumulative effect by two effective combined means to manage root-knot nematodes as the best opportunity in reducing the nematode population and improving plant health.

This introduces an ideal integration of management components against soil borne diseases like root-knot nematode. All management components in the study viz. the two bioagents, bioregulator and the nematicide are environment-friendly economic material and easy to apply by farmers. The British Germans Seed Company has achieved a 50\% reduction in the plant emergence time by using seed priming (Burks 2008). The economic effects of sugarbeet seed priming in the UK have resulted in a
$4 \%$ root yield gain and a technological yield of sugar of 5\% (Jaggard et al. 2009).

Effect on main yield components of sugarbeet: 6. Effect of multiple trails for controlling root- knot nematodes on roots yield (tons/ fed):

Results in Table (6) demonstrate impact of compound attempts to control root-knot nematodes on roots yield /fed. Variety effect exposed that sugarbeet variety, Helsinki achieved average of 23.30 tons root yield /fed, soaring sugarbeet variety, Sahar which scored 19.67 tons /fed. With significant difference at $\mathrm{P} \leq 0.05$. Regarding effect of plowing depth, findings showed that depth of $30 \mathrm{~cm}$ scored the highest tonnage ( 22.24 /fed.), followed by $40 \mathrm{~cm}$-plowing depth (21.37 tons/fed.) without significant difference between them.

Results in Table (6) also, signify that management treatments had distinct effect on roots yield /fed. Treatment T5 (EPD + Nemastop) achieved the highest rank in this concern (25.893 ton roots /fed.) followed T2 (Nemastop) - 23.119 ton roots /fed. with significant difference between them at $\mathrm{P} \leq 0.05$. The minimal effect recorded for management treatment $\mathrm{T}_{3}$ (Vaydet) 18.633 ton roots /fed.).

The effect interaction of combined treatments can be deduced from Table (6), as variety $\times$ plowing depth $(\mathrm{V} \times \mathrm{P})$; the highest level of tonnage roots/fed. (24.32) achieved by sugarbeet variety, Helsinki at plowing depth $40 \mathrm{~cm}$. The second ranked combination was also, sugarbeet variety, Helsinki but at plowing depth $30 \mathrm{~cm}$ (23.89 ton roots /fed.) without significant difference between them.

Table 6. Effect of multiple approaches for controlling root- knot nematodes on root yield (ton/ fed) in sugarbeet field by combine analysis of 2016/ 17 and 2017/ 18 growing seasons

\begin{tabular}{|c|c|c|c|c|c|c|c|c|}
\hline \multirow{2}{*}{ Varieties } & \multirow{2}{*}{$\begin{array}{c}\text { Plowing } \\
\text { depth }\end{array}$} & \multicolumn{6}{|c|}{ Treatments } & \multirow{2}{*}{ Mean } \\
\hline & & $\overline{T_{1}}$ & $\mathbf{T}_{2}$ & $\mathbf{T}_{3}$ & $\mathbf{T}_{4}$ & $\mathbf{T}_{5}$ & $\mathbf{T}_{6}$ & \\
\hline \multirow{3}{*}{$\begin{array}{c}\text { Polygerm } \\
\text { Sahar }\end{array}$} & 30 & 24.197 & 23.536 & 16.483 & 17.100 & 21.667 & 4.611 & 20.60 \\
\hline & 40 & 13.625 & 22.919 & 12.644 & 15.728 & 27.172 & 7.044 & 18.42 \\
\hline & 50 & 17.703 & 24.772 & 16.605 & 15.913 & 25.024 & 12.748 & 20.00 \\
\hline \multicolumn{2}{|c|}{ Mean } & 18.508 & 23.743 & 15.244 & 16.247 & 24.621 & 8.135 & 19.67 \\
\hline \multirow{3}{*}{$\begin{array}{c}\text { Monogerm } \\
\text { Helsinki }\end{array}$} & 30 & 25.922 & 20.348 & 19.512 & 20.557 & 33.108 & 15.162 & 23.89 \\
\hline & 40 & 19.127 & 23.669 & 25.337 & 26.449 & 26.998 & 13.348 & 24.32 \\
\hline & 50 & 19.419 & 23.470 & 21.217 & 22.965 & 21.390 & 12.296 & 21.69 \\
\hline \multicolumn{2}{|c|}{ Mean } & 21.489 & 22.496 & 22.022 & 23.323 & 27.165 & 13.602 & 23.30 \\
\hline \multirow{3}{*}{$\begin{array}{l}\text { Plowing } \\
\text { depth }\end{array}$} & 30 & 25.059 & 21.942 & 17.998 & 18.828 & 27.387 & 9.887 & 22.24 \\
\hline & 40 & 16.376 & 23.294 & 18.991 & 21.088 & 27.085 & 10.196 & 21.37 \\
\hline & 50 & 18.561 & 24.121 & 18.911 & 19.439 & 23.207 & 12.522 & 20.85 \\
\hline Mean & & 19.999 & 23.119 & 18.633 & 19.785 & 25.893 & 10.868 & 21.49 \\
\hline
\end{tabular}

$\mathrm{T}_{1}=\mathrm{EPD}, \mathrm{T}_{2}=$ Nemastop, $\mathrm{T}_{3}=$ Vaydet, $\mathrm{T}_{4}=\mathrm{EPD}+$ Abamectin, $\mathrm{T}_{5}=\mathrm{EPD}+$ Nemastop, and $\mathrm{T}_{6}=$ Control

$\begin{array}{lc}\text { L.S.D } & \\ \text { Varieties (V) } & 0.358 \\ \text { Plowing depth (P) } & 0.383 \\ \text { Treatments (T) } & 0.745 \\ \text { V x P } & 0.543 \\ \text { V x T } & 1.054 \\ \text { P x T } & 1.288 \\ \text { V x P x T } & 1.825\end{array}$


For the interaction effect of joined treatments variety $\times$ Managements treatments $(\mathrm{V} \times \mathrm{T})$, sugarbeet variety, Helsinki $\times$ Treatment T5 (EPD + Nemastop) gave the highest tonnage /fed. (27.165 roots tons). Followed by Sahar variety $\times$ Treatment T5 $($ EPD + Nemastop) - 24.621 root tons /fed. with significant difference between them at $\mathrm{P} \leq 0.05$.

Regarding interaction effect of plowing depth $\times$ management treatment $(\mathrm{P} \times \mathrm{T})$ on roots tonnage /fed., in the lead plowing depth $30 \mathrm{~cm} \times$ Treatment T5 (EPD + Nemastop) scored 27.387 tons followed by plowing depth $40 \mathrm{~cm} \times$ Treatment T5 (EPD + Nemastop) 27.085 tons/fed. without significant difference between them at $\mathrm{P} \leq 0.05$ (Table, 6).

The combined treatments of variety $\times$ plowing depth $\times$ management treatment $(\mathrm{V} \times \mathrm{P} \times \mathrm{T})$ had an interaction effect on roots tonnage /fed. as in the lead sugarbeet variety, Helsinki $\times$ plowing depth $30 \mathrm{~cm} \times$ Treatment T5 (EPD + Nemastop) - 33.108 tons /fed. followed by Sahar variety at plowing depth $40 \mathrm{~cm}$ with Treatment T5 (EPD + Nemastop) - 27.172 ton roots /fed, with significant difference between them at $\mathrm{P} \leq$ 0.05 (Table, 6).

\section{Effect of multiple approaches for controlling} root- knot nematodes on sugar yield (ton/ fed):

Results in Table (7) showed that varieties had no significant difference between them for sugar yield tonnage/fed. at $\mathrm{P} \leq 0.05$. Concerning plowing depth effect on sugar yield/fed., plowing depth $30 \mathrm{~cm}$ was in the front (4.14 tons sugar/fed.), followed by plowing depth $40 \mathrm{~cm}$ followed by plowing depth $50 \mathrm{~cm}(4.03$ and 3.87 tons sugar, respectively), with significant differences among them at $\mathrm{P} \leq 0.05$. The best management effect on sugar yield / fed. was $\mathrm{T}_{5}$ (EPD + Nemastop) achieved 4.943 tons sugar/fed. followed by $\mathrm{T}_{2}$ (Nemastop) that recorded 4.374 tons sugar/fed. without significance difference between them at $\mathrm{P} \leq$ 0.05 .

Table 7. Effect of multiple approaches for controlling root- knot nematodes on sugar yield (tons/ fed) in sugarbeet field by combine analysis of 2016/17 and 2017/ 18 growing seasons.

\begin{tabular}{|c|c|c|c|c|c|c|c|c|}
\hline \multirow{2}{*}{ Varieties } & \multirow{2}{*}{$\begin{array}{c}\text { Plowing } \\
\text { depth }\end{array}$} & \multicolumn{6}{|c|}{ Treatments } & \multirow{2}{*}{ Mean } \\
\hline & & $\mathbf{T}_{1}$ & $\mathbf{T}_{2}$ & $\mathbf{T}_{3}$ & $\mathbf{T}_{4}$ & $\mathbf{T}_{5}$ & $\mathbf{T}_{6}$ & \\
\hline \multirow{3}{*}{$\begin{array}{c}\text { Polygerm } \\
\text { Sahar }\end{array}$} & 30 & 4.407 & 4.273 & 2.852 & 2.932 & 4.161 & 0.721 & 3.73 \\
\hline & 40 & 2.538 & 4.269 & 2.117 & 2.763 & 5.275 & 1.111 & 3.39 \\
\hline & 50 & 3.176 & 4.673 & 2.644 & 2.772 & 4.823 & 2.004 & 3.62 \\
\hline \multicolumn{2}{|c|}{ Mean } & 3.374 & 4.405 & 2.538 & 2.822 & 4.753 & 1.279 & 3.58 \\
\hline \multirow{3}{*}{$\begin{array}{c}\text { Monogerm } \\
\text { Helsinki }\end{array}$} & 30 & 4.998 & 3.919 & 3.602 & 4.021 & 6.275 & 2.596 & 4.56 \\
\hline & 40 & 3.766 & 4.579 & 4.820 & 5.140 & 5.001 & 2.309 & 4.66 \\
\hline & 50 & 3.678 & 4.531 & 4.082 & 4.223 & 4.121 & 2.283 & 4.13 \\
\hline \multicolumn{2}{|c|}{ Mean } & 4.148 & 4.343 & 4.168 & 4.461 & 5.133 & 2.396 & 4.45 \\
\hline \multirow{3}{*}{$\begin{array}{l}\text { Plowing } \\
\text { depth }\end{array}$} & 30 & 4.702 & 4.096 & 3.227 & 3.476 & 5.218 & 1.658 & 4.14 \\
\hline & 40 & 3.152 & 4.424 & 3.468 & 3.952 & 5.138 & 1.710 & 4.03 \\
\hline & 50 & 3.427 & 4.602 & 3.363 & 3.498 & 4.472 & 2.143 & 3.87 \\
\hline \multicolumn{2}{|c|}{ Mean } & 3.761 & 4.374 & 3.353 & 3.642 & 4.943 & 1.837 & 4.01 \\
\hline
\end{tabular}

$\mathrm{T}_{1}=\mathrm{EPD}, \mathrm{T}_{2}=$ Nemastop, $\mathrm{T}_{3}=$ Vaydet, $\mathrm{T}_{4}=\mathrm{EPD}+$ Abamectin, $\mathrm{T}_{5}=\mathrm{EPD}+$ Nemastop, and $\mathrm{T}_{6}=$ Control

$\begin{array}{lc}\text { L.S.D } & \\ \text { Varieties (V) } & 0.135 \\ \text { Plowing depth (P) } & 0.087 \\ \text { Treatments (T) } & 0.139 \\ \text { V x P } & 0.161 \\ \text { V x T } & 0.228 \\ \text { P x T } & 0.279 \\ \text { V x P x T } & 0.383\end{array}$
interaction effect on sugar yield /fed. And ere were significant differences among them $\mathrm{P}<$ depth had the lead in sugar production ton/fed. (4.66). followed by the same variety at $30 \mathrm{~cm}$-plowing depth (4.56 tons/ fed.), followed by Sahar variety at $30 \mathrm{~cm}$ plowing depth (3.73 tons /fed.). Interaction effect of variety $\times$ management treatments on sugar yield/fed. exhibited some significant differences at $\mathrm{P} \leq 0.05$, sugarbeet variety, Helsinki $\times \mathrm{T}_{5}$ (EPD + Nemastop) recorded the highest sugar yield/fed. (5.133 tons), followed by Sahar variety with the same Management treatment $\left(\mathrm{T}_{5}\right)-4.753$ tons sugar/ fed., whereas the weakest effect obtained by sugarbeet variety, Sahar with treatment $\left(\mathrm{T}_{3}=\right.$ Vaydet $)$, that had value of 2.822 tons sugar /fed., (Table, 7).

Illustration in Table (7) revealed that interaction of plowing depth $\times$ management treatments for $30 \mathrm{~cm}$ plowing depth $\times \mathrm{T}_{5}$ (EPD + Nemastop) recorded the first rank in sugar production tons/ fed. (5.218 tons) followed $40 \mathrm{~cm}$-plowing depth with the same treatment $\left(\mathrm{T}_{5}\right)-5.138$ tons sugar $/ \mathrm{fed}$. without significance at $\mathrm{P} \leq 0.05$, followed by $30 \mathrm{~cm}$-plowing depth with $\mathrm{T}_{1}$ (EPD) - 4.702 tons sugar /fed., whereas, the slightest activity was at $30 \mathrm{~cm}$-plowing depth with $\left(\mathrm{T}_{3}=\right.$ Vaydet $)-3.227$ tons sugar /fed. The combined treatments of variety $\times$ plowing depth $\times$ management treatment $(\mathrm{V} \times \mathrm{P} \times \mathrm{T})$ had significant interaction effect occasionally at $\mathrm{P} \leq 0.05$ on sugar yield/fed., whereas, in the front was activity of Helsinki variety at $30 \mathrm{~cm}$ plowing depth with T5 (EPD + Nemastop) - 6.275 tons sugar /fed., followed by Sahar variety at $40 \mathrm{~cm}-$ plowing depth by $\mathrm{T}_{5}$ (EPD + Nemastop) with significant difference at $\mathrm{P} \leq 0.05$. Whereas, the inadequate effect was for Sahar variety at $40 \mathrm{~cm}$ plowing depth with Vaydet (2.117 tons sugar/fed.) 
In short, from Table 4-6, concerning roots, top and sugar yields per fed., it could be seen that at the level of individual treatments i.e. variety, plowing depth and treatment and their effect on yields (root, top, sugar/fed.), sugarbeet variety, Helsinki overcome Sahar variety. Also, $30 \mathrm{~cm}$-plowing depth had the lead in achieving preferred results, as well treatments $\mathrm{T} 5$ (EPD + Nemastop), $\mathrm{T}_{2}$ (Nemastop) and $\mathrm{T}_{1}$ (EPD). Interactions of combined treatment as well showed distinguished results for those parameters mentioned above as combined treatments implied one of those distinguish individuals. Positive returns towards sugarbeet plants are consequences for what early happened in the early stages of sugarbeet plants development (as illustrated in three previous Tables), from preserving higher number of sugarbeet plants /fed. after thinning and at harvest and reducing loss. These are in consistency with findings of Chomontowski et. al. (2019) stated that the higher vigor of seeds caused by priming was associated with the acceleration of leaf development and the increase in plant dry matter during the growing season. As a result, seed priming contributes to a significant increase in the technological yield of sugar. Also, Gohar et. al. (2013) pointed out that sugarbeet varieties categorized as tolerant were the best genotype with highest beet root yield, sugar recovery and ultimately gave maximum sugar yield.

There is no conformity in the literature relating to the effect of tillage practices on the pathogen stress and the resultant disease severity on the subsequent crops. Some investigations report that conservative tillage practices reduce disease intensity on the following crops, measured up with minimum or no tillage pattern (Hofgaard et al. 2016). In contrast, other studies suggest that conventional tillage practices enhance some diseases while they reduce others over time (Schroeder and Paulitz 2006). Among the few studies on possible interactions between two or more factors showed significant and complex interactions between seedbed physical as well as chemical components, crop variety and their overall impact on the disease severity (You and Barbetti 2017a; You and Barbetti 2017b; You et al. 2017). Tillage practices can markedly affect the germination environment of seeds by inducing changes in temperature and moisture of the topsoil, seed-soil contact and the amount of crop residues. (Pittelkow et. al., 2015).

Proper protection of crops is very important for a good sugarbeet yield. Proper protection makes repeated use of chemicals to seeds and young plants. At West Nubaria District where experiments are performed.

\section{Conclusions and Recommendations:}

Based on the findings of the two examined seasons conducted under agroecological conditions of West Nubaria district for the effect of the variety, plowing depth and management treatments applied to sugarbeet seeds on root-knot nematode infestation indices, roots and sugar yields per fed, it can be concluded:

- Effect of treatments individually or in combinations on root-knot nematode parameters, as nematodes number/g soil, knot disease severity $\%$ and drop rate $\%$. Results indicated that sugarbeet variety Helsinki overcame Sahar variety positively; also, $30 \mathrm{~cm}$ plowing depth outperformed the other two depths in the same issues. Managements treatments distinctly revealed that (EPD + Nemastop), (Nemastop) and (EPD) achieved the best results to reduce all studied root-knot nematode parameters. Interaction effect of combined treatments got promising results as they implied any of individual treatment that previously showed positive results concerning the same nematode parameters.

- At the level of variety, monogerm sugarbeet variety, Helsinki outperformed polygerm variety, Sahar. At plowing depth level, $30 \mathrm{~cm}$-plowing depth was mostly had superior positive effect on all recorders of the abovementioned readings.

- Root and sugar yield per fed., it could be seen that at the level of individual, sugarbeet variety, Helsinki overcome Sahar variety. Also, $30 \mathrm{~cm}$-plowing depth had the lead in achieving preferred results, as well treatments (EPD + Nemastop), (Nemastop) and (EPD). Interactions of combined treatment as well showed distinguished results for those parameters mentioned above as combined treatments implied one of those distinguish individuals.

- Understanding and manipulating cropping practices and seed technology, are assuming an increasingly important role as an alternative to chemical pesticides. This scenario highlights the importance to define not only how seed germination and seedling emergence (SGE) will be impacted in the absence of one or more current chemical seed treatments, but to explore the effectiveness of nonchemical seed treatments such as seed priming (Dewar 2017; Kathage et al. 2017)..

- The appropriate selection of varieties for an exacting product area contributes to better and steadier production of cultivated crops. In order to costeffective production and processing of sugarbeet cultivation it is reasonable to saw varieties of all three main directions of selection: $\mathrm{Z}$ (high content of sugar), $\mathrm{N}$ (normal) and $\mathrm{E}$ (high yield) (Bojovic et al., 2014).

\section{Acknowledgement}

The authors would like to acknowledge the fund provided by Science and Ttechnology Developmental Fund ( STDF), Egypt -China Cooperation Fund, Project ID: 30369 . 


\section{References}

Abad P, Favery B, Rosso MN, Castagnone-Sereno P. (2003). Root-knot nematode parasitism and host response: Molecular basis of a sophisticated interaction. Mol Plant Pathology. 4: 217-224.

Agami, K. M; M. M. Abd- El Rahman and H. M. Aboul- Nour (2010). Effect of soil leveling techniques and sowing methods under different plowing depths on sugarbeet yield and quality in Nubaria region. Minufiya J. Agric. Res. Vol. 35 No. 6: 2063 - 2075.

Annual Report for Sugar Crops (2008). Sugar Crops Council, Ministry of Agriculture and Land Reclamation, Giza, Egypt.

Annual Report for Sugar Crops (2018). Sugar Crops Council, Ministry of Agriculture and Land Reclamation, Giza, Egypt.

Atiyeh, R.M., Lee, S., Edwards, C.A., Arancon, N.Q. and Metzger, J.D. (2002). The effects of humic acids derived from earthworm-processed organic wastes on plant growth. Bioresource Technology 84: 7-14.

Barker, K.R. (1985). Nematode Extraction and Bioassays. In: Barker, K.R., C.C. Carter and J.N. Sasser (eds.), An Advanced Treatise on Meloidogyne, Vol. II Methodology, pp: 19-35. A Co-Op.

Bojović, R., Glamočlija, Đ., Popović, Vera, Popović, B., Filipović ,V., Kuzevski, J., 2014. Sugarbeet yield parameters on carbonate chernozem soil type. Agriculture and Forestry, Vol. 60. Issue 3: 41-53, 2014, Podgorica.

Burks, E. (2008). Next generation priming. $\mathrm{Br}$ Sugarbeet Rev 76:6-9

CECD. (2019). List of varieties eligible for seed certification. Fodder beet and Sugarbeet . $35 \mathrm{Pp}$ http://www.oecd.org/agriculture/seeds/documents /codes-schemes-list-of- varieties-fodder-beet-andsugar-beet.pdf.

Chomontowski C., · H. Wzorek · S. Podlask. (2019). Impact of sugarbeet seed priming on seed quality and performance under diversified environmental conditions of germination, emergence and growth. Journal of Plant Growth Regulation. Pp 1-7.

Dadlani, M., V.V. Shenoy and D.V. Seshu, (1992). Seed coating to improve stand establishment in rice. Seed Sci. Technol., 20: 307-313.

Dewar AM (2017) The adverse impact of the neonicotinoid seed treatment ban on crop protection in oilseed rape in the United Kingdom. Pest Manag Sci 73:1305-1309.

Draycott P.; H. Smith; V. Heyes and J. Prince (2002). Seed advancement - theory and practice. Brit. Sug. Beet Rev., 70:2-5.

Duncan, D B. (1955). Multiple range and multiple F tests. Biometrics 11:1-42.

Evans, K., Webster, R. M., Halfobd, P. D., Barker, A. D., and Russell, M. D. (2002). Site-specific management of nematodes-Pitfalls and practicalities. Journal of Nematology. 34:194-199.

FRYE, J. W. (2009). Efficacy of Novel Nematicide Seed Treatments for the control of Heterodera glycines in Soybean Production .M.S Thesis, North Carolina State University. U.S.A. 50pp.

GAIN Report Number EG-19006. (2019). Increasing Sugar Supply on Expanded Beet Production. Sugar Annual Cairo- Egypt April, 2019: Pp. 9.

Ghebru, M.G., du Toit, E.S and Steyn, J.M. (2007) Water and nutrient retention by aquasoil and Stockosorb polymers. University of Pretoria, Department of plant production and soil science, Pretoria, South Africa.

Gohar, I.M.A. and M.F. Maareg (2005). Relationship between crop losses and initial population densities of root-knot nematode, Meloidogyne in soil of sugarbeet grown in West Nubaria district. Egypt. J. Agric. Res. 83 (4): 1315-1328.

Gohar, I.M.A.; A.A. Abo El-Ftooh and K.M. Agami. (2014). Evaluation of Nematicide Seed Treatments for the control of Root-knot Nematode, Meloidogyne javanica in sugarbeet production. Minufiya J. Agric. Res. Vol. 39 No.6:1841- 1854.

Gohar, I.M.A.; K.M. Agami and M.M. Abd-El Rahman. (2009). Integrating some biocontrol agents along with Agrispon and Furadan (Carbofuran) to control root-knot nematode, Meloidogyne incognita Kofoid \& White (Chitwood) Infesting sugarbeet crop in Nubaria. J. Biol. Chem. Environ. Sci., 2009, Vol. 4(1): 445461.

Gohar, I.M.A; A.A. Abo El-Ftooh; M. S. Saleh and Mohamed, Kh. El-Shnawey .( 2013). Tolerance effect of Some Sugarbeet Varieties to Root Knot Nematode, Meloidogyne incognita and Efficacy of Nemacur (Fenamiphos) Control under Field Conditions. Alexandria Science Exchange journal. Vol.34, No.1.129-139.

Gorim L. Y. (2014). Effects of seed coating on germination and early seedling growth in cereals. Ph.D in Agricultural Sciences. Institute of Plant Production and Agroecology in the Tropics and Subtropics, University of Hohenheim. Pp. 132.

Gorim, L., Asch, F. and Trimborn, M. (2009) Seed coating with hydro-absorbent properties as possible mitigation strategy for unreliable rainfall patterns in early-sown sorghum. In: Tielkes, E. (ed.) Biophysical and socio-economic frame conditions for the sustainable management of natural sources: book of abstracts; [October 6th 8th, 2009, University of Hamburg, Department of Biology] / Tropentag 2009, international research on food security, natural resource management and rural development.

Harris JC, Cottrell SL, Plummer S, Lloyd D. (2001). Antimicrobial properties of Allium sativum (garlic). Appl. Microbiol. Biotechnol; 57:282-286.

Hartman, K.M.; Sasser, J.N. (1985) Identification of Meloidogyne species on the basis of deferential 
host test and perineal-pattern morphology. In An Advanced Treatise on Meloidogyne. Biology and Control; Barker, K.R., Carter, C.C., Sasser, J.N., Eds.; North Carolina State University: Raleigh, NC, USA, Volume I, pp. 69-77.

Hassan, Z.A., Young, S.D., Hepburn, C. and Arizal, R. (1990). An evaluation of urea-rubber matrices as slow-release fertilizer. Fertilizer Research 22: 6370.

Hofgaard IS, Seehusen T, Aamot HU et al (2016) Inoculum potential of Fusarium spp. Relates to tillage and straw management in Norwegian fields of spring oats. Front Microbiol 7:556.

Jaggard KW, Qi A, Ober ES. (2009). Capture and use of solar radiation, water, and nitrogen by sugarbeet (Beta vulgaris L.). J Exp Bot 60(7):1919-1925.

Kathage J, Castañera P, Alonso-Prados JL et al (2017) The impact of restrictions on neonicotinoid and fipronil insecticides on pest management in maize, oilseed rape and sunflower in eight EU regions. Pest Manag Sci. https://doi.org/10.1002/ps.4715

Kolarić Ljubiša, Vera M. Popović, Jelena Paunović ; Ljubiš, Ljubiša Živanović, Jela Ikanović, and Vladimir Sikora.(2015). Sugarbeet and quality in the agroecological conditions of Central Banat, Serbia.. Agriculture \& Forestry, Vol. 61, Issue 4: 33-41

Maareg M. F; I. M.A. Gohar and A.M. Abdel Aal 2005 . Susceptibility of twenty one sugarbeet varieties to the root-knot nematode, Meloidogyne incognita at West Nubaria District. . Egypt. J. Agric. Res., 83 (2): 789- 801.

Mackowiak, C.L., Grossl, P.R. and Bugbee, B.G. (2001) Beneficial effects of humic acids on micronutrients availability to wheat. Soil Science Society of America Journal 65: 1744-1750.

Mikkelsen, R.L., Behel Jr., A.D. and Williams, H.M. (1993). Addition of gel forming hydrophilic polymers to nitrogen fertilizer solutions. Fertilizer Research 36: 55-61.

Nwauzor, E.C., 1998. Screening Cassava (Manihot esculentum (rantz.) varieties for Resistance to Root-knot Nematode, Meloidogyne incognita, kofoid and white 1919.

Orzeszko-Rywka A. and S. Podlaski. (2003).The effect of sugarbeet seed treatments on their vigour. Plant Soil Environ. 49, (6): 249-254.

Pittelkow CM, Linquist BA, Lundy ME et al (2015) When does no-till yield more? A globa metaanalysis. F Crop Res 183: 156-168.

Powell, A.A. and Matthew, S. (1988). Seed treatment: development and Prospect. Outlook on Agriculture 17: 93-103.

Putter I.; J.G. Maconnel; F.A. Preiser; A.A. Haidri; S.S. Ristich; R.A. Dybas (1981). Avermectins: novel insecticides, acaricides and nematicides from a soil microorganism. Experientia 37, 963964.
Sasser, J.N., C.C. Carter and K.M. Hartman, 1984. Standardization of Host Suitability Studies and Reporting of Resistance to Root-knot Nematode, Raleigh, N.C. U.S.A. Pp: 7.

Schroeder KL, Paulitz TC (2006) Root diseases of wheat and barley during the transition from conventional tillage to direct seeding. Plant Dis 90:1247-1253.

Scott, J.M. 1998: Delivering fertilizers through seed coatings. Journal of Crop Production 1: 197-220.

Scott, J.M., Jessop, R.S., Steer, R.J. and Mclachlan, G.D. (1987). Effects of nutrients seed coating on the germination of wheat and oats. Fertilizer Research 14: 205-217.

Shamloeian, Mohammad (2017) The effect of seed coating with fertilizer containing nutrients and growth stimulants TEPROSYN, KADOSTIM, ZAGROOT on germination and seedling growth of sugarbeet. Masters thesis, University of Mohaghegh Ardabili

Silcock, R., and Smith, F. (1982). Seed coating and localized application of phosphate for improving seedling growth of grasses on acid, sandy red earth. Australian Journal Agricultural Research 33: 785802.

Snedecor, George W. and W.G. Cochran (1989). Statistical Methods, Eighth Edition, Iowa State University press. Pp. 491.

Sikora, R. A and Fernandez, E. (2005). Nematode parasites of vegetables. In: Luc, M., Sikora, R. A and Bridge, J. (eds). Plant Parasitic Nematodes in Subtropical and Tropical Agriculture. CAB International, UK. pp $319-393$.

Steel, R.G.D. and Torrie, J.H. (1981). Principles and procedures of statistics, a biometrical approach. $2^{\text {nd }}$ ed. By Mc Graw-Hill International Book Company, Singapore, pp. 633.

Süheri, S.,(2007). Farklı Gelişme Safhalarında Uygulanan Farklı Sulama Seviyelerinin Şeker Pancarı Verimi Üzerine Etkileri, T.C.Selçuk Üniversitesi Fen Bilimleri Enstitüsü, Tarımsal Yapılar ve Sulama Anabilim Dalı, Konya .

Turne, M.J.; J.M. Schaeffer (1989). Mode of action of ivermectin. In: W.C. Campbell (ed.): Ivermectin and Abamectin, pp. 73-88. Springer-Verlag, New York.

Vyn, T.J. and Marua, M. (2001) Polymer seed coatings: Sufficient Risk Reduction for early plant corn. Traditional risks of early planting of uncoated seeds. 56 ${ }^{\text {th }}$ Annual Corn and Sorghum Research Conference. 1-11. Purdue University.

You MP, Barbetti MJ (2017a) Severity of phytophthora root rot and pre-emergence damping-off in subterranean clover influenced by moisture, temperature, nutrition, soil type, cultivar and their interactions. Plant Pathol 66:1162-1181.

You MP, Barbetti MJ (2017b) Environmental factors determine severity of Rhizoctonia damping-off and root rot in subterranean clover. Australas Plant Pathol 46:357-368. 
You MP, Rensing K, Renton M, Barbetti MJ (2017). Modeling effects of temperature, soil, moisture, nutrition and variety as determinants of severity of Pythium damping-off and root disease in subterranean clover. Front Microbiol 8:2223.
Xue QY, Chen Y, Li SM, (2009). Evaluation of bacterial strains of acinetobacter and nitrobacteria as potential biocontrol agents against Ralstonia wilt of tomato. Biocontrol.; 48:252-258.

\section{تقييم بعض إستراتيجيات لمكافحة نيماتودا تعقد الجذورفي حقول بنجر السكر بمنطقة غرب النويارية}

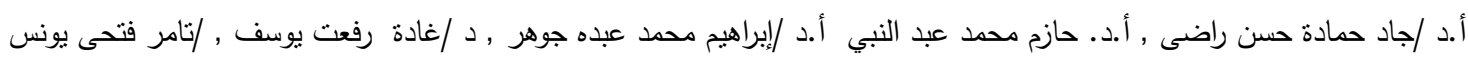

أجريت تجربتان ميدانيتان في منطقة غرب النوبارية ، على مدار موسمين متتاليين من 2017/2016 - 2018/2017 لتقييم إستراتيجيات متعددة تستتد إلى تقليل الفترة مابين زراعة البذور وظهور البادرة وذلك من خلال زيادة سرعة الإنبات وظهور البادرات لتقييم أهم إستراتيجية للهروب عندي

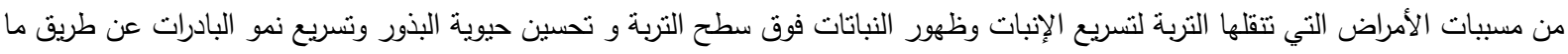

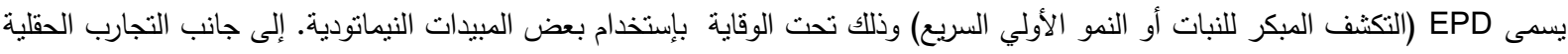
تم إجراء تجربة أصص في الهواء الطلق مدتها 60 يوما لتقييم حساسية صنفي بنجر السكر ( سحر و هلسنكي) لنيماتودا تعقد الجذور ميليدوجين إنكوجنيتا.وكان تصميم التجارب الحقلية عبارة عن تصميم القطع المنشقة مرتين، حيث كان الصنف في القطعة الرئيسية وأعماق الحرث كان في

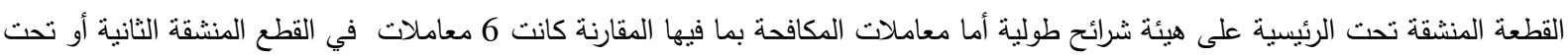

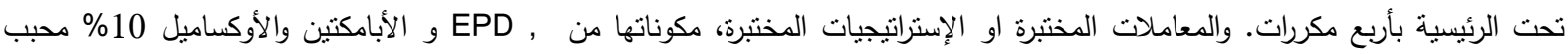
والنيماستوب وتوليفات فيما بينها ومقارنتها مع معاملة الكنترول. أظهر المخطط الكمي كانتو سانشيز لتقدير مدى ملاعمة العائل لنيماتودا تعقد الجذور وأوضح أن صنف بنجر السكر ، هلسنكي هو متحمل لتلك الديدان والصنف سحر حساس لها.كما أوضح تحليل النباين للبيانات المجمعة للموسمين المدروسين معنوياً وبأحتمال P

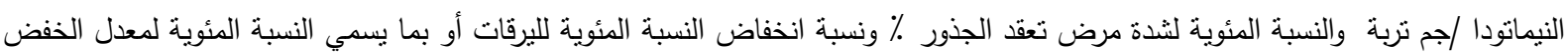

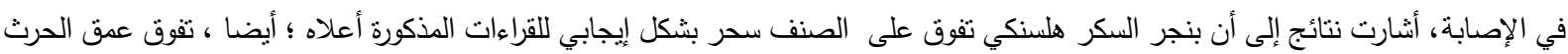

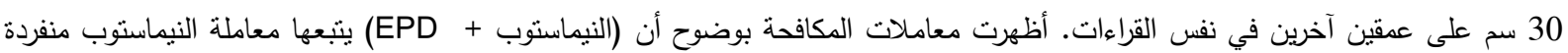
ثم EPD منفردة حققوا أفضل النتائج لخفض جميع قراءات نيماتودا تعقد الجذور وعلى الأرجح مع عمق حرث 30 سم · حقق نأثير التفاعل

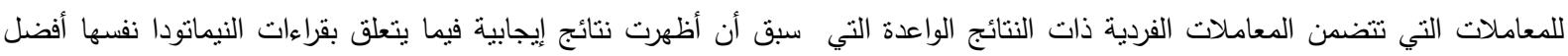

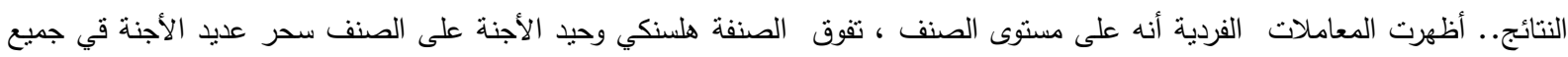
القياسات المدروسة ـ عند مستوى عمق الحرث ، كان لعمق 30 سم تأثنير إيجابي متفوق بالنسبة لأعماق الحرث المختبرة. على مستوى معاملات

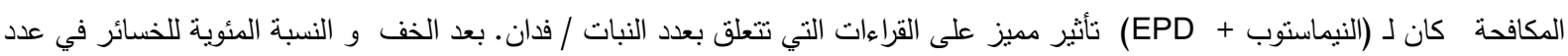
النباتات ، يليه في التأثير معاملة النيماستوب ثم معاملة EPD ـ فيما يتعلق بتأثير التفاعل ، يمكن ملاحظة أن جميع النتائج الواعدة للمعاملات

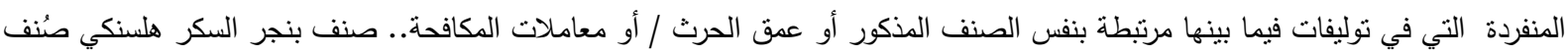
على انه متحمل وبالنسبة لمحصول الجذور ومحصول السكر، تفوق الصنف هلسنكي على الصنف سحر • وأيضا عمق الحرث 30 سم كان في المقدمة في تحقيق النتائج المفضلة وكذلك معاملة (النيماستوب + EPD) يتبعها معاملة النيماستوب ثم معاملة EPD. فيما بتعلق بتأثير التفاعل للتوليفات بين المعاملات أيضاً بالمثل أظهرت نتائج مميزة للقراءات المذكورة آنفاً طالما كان من مكوناتها المعاملات التي أظهرت تقوفة منفة منفردة. 